\title{
Albania: Financial System Stability Assessment, including Reports on the Observance of Standards and Codes on the following topics: Banking Supervision and Payment Systems
}

This Financial System Stability Assessment on Albania was prepared by a staff team of the International Monetary Fund and the World Bank as background documentation for the periodic consultation with the member country. It is based on the information available at the time it was completed on July 22, 2005. The views expressed in this document are those of the staff team and do not necessarily reflect the views of the government of Albania or the Executive Board of the IMF.

The policy of publication of staff reports and other documents by the IMF allows for the deletion of market-sensitive information.

To assist the IMF in evaluating the publication policy, reader comments are invited and may be sent by e-mail to publicationpolicy@imf.org.

Copies of this report are available to the public from

International Monetary Fund • Publication Services

700 19th Street, N.W. • Washington, D.C. 20431

Telephone: (202) 6237430 • Telefax: (202) 6237201

E-mail: publications@imf.org • Internet: http://www.imf.org

Price: $\$ 15.00$ a copy

\section{International Monetary Fund \\ Washington, D.C.}





\title{
INTERNATIONAL MONETARY FUND
}

\author{
ALBANIA
}

\section{Financial System Stability Assessment}

\author{
Prepared by the Monetary and Financial Systems and European Departments \\ Approved by Stefan Ingves and Michael Deppler
}

July 22, 2005

This Financial System Stability Assessment (FSSA) is based on the work of the joint IMF/World Bank Financial Sector Assessment Program (FSAP) mission that visited Tirana from February 7-21, 2005 and March 21-24, 2005.

The FSAP team comprised Lalit Raina (Mission leader, World Bank), Laura Kodres (Deputy mission leader, RES), Edward Frydl, Andrea Maechler, Geoffrey Oestreicher (all IMF), Massimo Cirasino, Gabriella Ferencz, Peter B. Kyle, Serap Oguz-Gonulal, Constantinos Stephanou, Greta Minxhozi, Marius Vismantas (all World Bank); Peter Hayward (retired IMF), and Anne John (World Bank, Program Assistant). The main findings of the FSAP are:

- The Albanian financial system does not appear to be highly vulnerable to immediate macro-economic or financial sector shocks, but accelerating credit growth and increased competition arising from the recent privatization of the dominant (savings) bank may put pressure on the banking system, which represents some 90 percent of formal financial system assets, and the situation bears careful monitoring.

- $\quad$ The financial system is at an early stage of development and while the core legal and regulatory framework are in place, several recommendations are made that aim to broaden and deepen markets to encourage financial intermediation and more general use of the formal financial system.

- $\quad$ Nonbank financial institutions remain relatively small and are not currently a source of systemic vulnerability. However, the insurance sector is growing quickly and given its poor governance, financial accounting and reporting practices and a currently weak regulatory body it could pose a threat to the confidence in the financial system, weakened by the 1997 pyramid scheme.

- The banking supervisory framework has been strengthened in recent years with technical assistance from the Bank and Fund. However, Albania has too many financial sector regulatory entities given its current level of development and regulatory efficiency could be enhanced by merging the insurance, securities, and pension fund regulators as a first step and re-examining integration with banking supervision at a later date.

The main author of this report is Laura Kodres.

FSAPs are designed to assess the stability of the financial system as a whole and not that of individual institutions. They have been developed to help countries identify and remedy weaknesses in their financial sector structure, thereby enhancing their resilience to macroeconomic shocks and cross-border contagion. FSAPs do not cover risks that are specific to individual institutions such as asset quality, operational or legal risks, or fraud 


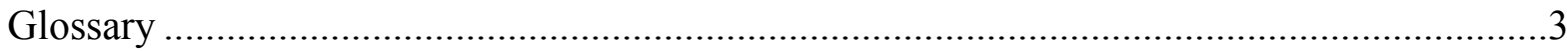

Executive Summary ................................................................................................

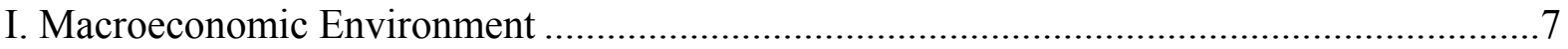

II. Monetary Policy and Liquidity Management..............................................................

III. Macroprudential Analysis of Risks to Financial Stability ............................................10

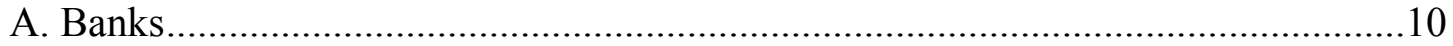

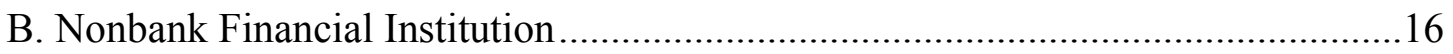

IV. Strengths and Vulnerabilities: the Financial Stability Policy Framework........................19

A. The Regulatory and Supervisory Framework ..............................................19

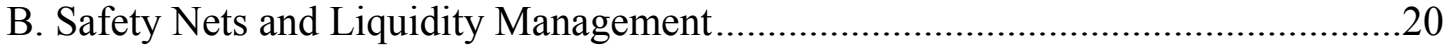

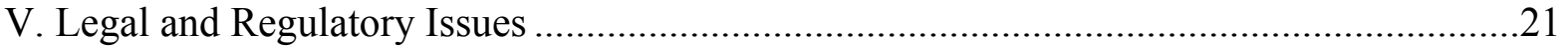

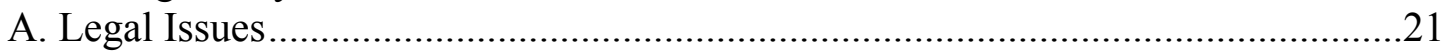

B. Anti-Money Laundering and Combating the Financing of

Terrorism $(\mathrm{AML} / \mathrm{CFT})$..........................................................................22

Tables

1. Aggregate Balance Sheet of Banks ....................................................................... 11

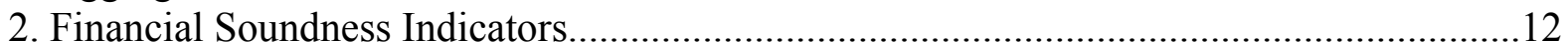

3. Effects of Stress Tests on the Banking System......................................................... 15

4. Recommended Action Plan to Improve Compliance of the Basel Core Principles.............26

5. Recommended Actions to Improve Observance of CPSS Core Principles and Central Bank

Responsibilities in Applying the CPs .................................................................. 31

Boxes

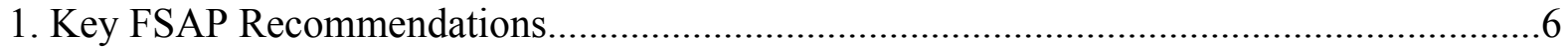

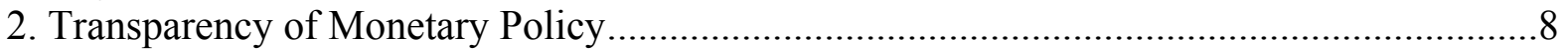

Annex

Summary Assessments and the Observance of Selected Financial Sector Standards and Codes. 


\section{GLOSSARY}

$\begin{array}{ll}\text { AML/CFT } & \text { Anti Money Laundering/Combating the Financing of Terrorism } \\ \text { ADI } & \text { Albanian Deposit Insurance } \\ \text { ASE } & \text { Albania Stock Exchange } \\ \text { ASC } & \text { Albanian Securities Commission } \\ \text { ASCU } & \text { Albanian Savings and Credit Unions } \\ \text { BoA } & \text { Bank of Albania } \\ \text { CAMEL } & \text { Capital, Assets, Management, Earnings, \& Liquidity ratings } \\ \text { CAR } & \text { Capital Adequacy Ratio } \\ \text { EU } & \text { European Union } \\ \text { FSAP } & \text { Financial Sector Assessment Program } \\ \text { FSVC } & \text { Financial Services Volunteer Corps } \\ \text { GDP } & \text { Gross Domestic Product } \\ \text { IAIS } & \text { International Association of Insurance Supervisors } \\ \text { IAS } & \text { International Accounting Standards } \\ \text { IFRS } & \text { International Financial Reporting Standards } \\ \text { ILF } & \text { Intraday Liquidity Facility } \\ \text { ISA } & \text { Insurance Supervisory Authority } \\ \text { LEK } & \text { Albanian Currency } \\ \text { MAFF } & \text { Mountain Area Finance Fund } \\ \text { MoF } & \text { Ministry of Finance } \\ \text { NPLs } & \text { Non-Performing Loans } \\ \text { OECD } & \text { Organization for Economic Co-operation \& Development } \\ \text { OIPISP } & \text { Office of Inspectors of Private Institutes of Supplementary Pensions } \\ \text { ROA } & \text { Return on Assets } \\ \text { RTGS } & \text { Real Time Gross Settlement } \\ \text { SDP } & \text { Supervisory Development Plan } \\ \text { SII } & \text { Social Insurance Institute } \\ \text { SOEs } & \text { State Owned Enterprises } \\ \text { T-Bill } & \text { Treasury Bill } \\ & \end{array}$




\section{EXECUTIVE SUMMARY}

The Albanian financial system does not appear to be highly vulnerable to immediate macro-economic or financial sector shocks. Moreover, the financial system's effect on the real economy is likely to be small as it is still in the early stages of development. Cash transactions dominate exchanges, although increasingly Albanians are gaining confidence and trust in both the government and the formal financial system after it was shaken during the 1997 pyramid scheme crisis. Prudent monetary and fiscal policies have contributed to a stable macroeconomic environment and much of the core financial sector legislative and regulatory framework is in place. However, the importance of a sustained implementation track record cannot be underestimated, especially given recent elections and a new set of policymakers. Policy continuity by both financial institutions and the regulatory authorities is needed to build public confidence in the formal financial sector and to keep systemic risks at bay.

Despite the dominance of informal cash-based transactions, the banking system is growing and intermediation is flourishing - in fact, credit growth is bordering on boom conditions. Accelerating credit growth and prospect for increased competition arising from the recent privatization of the largest bank may put pressure on the banking system, representing 90 percent of formal financial system assets. To date, the credit expansion has been funded by broader deposit-taking as more remittance income has been intermediated. Nonetheless, credit growth reached 50 percent (y-o-y) in April 2005 and, while still amounting to only some $10 \frac{1}{4}$ percent of GDP, the stage is set for a credit boom. Banks and supervisors have not yet witnessed a full credit cycle and thus may not be fully prepared. If problems arise in the banking sector and they are not adequately addressed, trust in other nascent financial institutions, such as insurance companies, may be impaired. The situation bears close attention not least because any financial sector problems could have implications for the conduct of monetary policy.

So far, however, the Bank of Albania's conduct of monetary policy has been sound and its liquidity management framework has been shown to function well. Nonetheless, the absence of a liquid secondary government securities market, highly concentrated holdings of government debt, and a weak interbank market remain potentially vulnerable elements in the evolving financial sector and could hinder the effectiveness of monetary policy. The central bank increasingly has the know-how and the tools, but credit extension is still not very responsive to interest rate changes from the central bank as the transmission to the real sector appears to be more via the exchange rate than directly via interest rates. Policy rates influence the dollar and euro interest rate spreads and thus the relative attractiveness of domestic currency (lek) deposits. In part, this is the result of a segmented and overly liquid banking sector - a situation that will rectify itself as the financial system matures. The central bank should continue to ensure its pricing of liquidity management operations are not advantageous vis-à-vis other banks and educate banks about the functioning of interbank markets. 
Stress tests suggest that the banking sector is fairly resilient to hypothetical shocks to foreign exchange risk, interest rate risk, and credit risks without causing systemic distress. The Albanian banking sector overall has performed well in recent years, with relatively high levels of earnings and capitalization and a low level of NPLs, but will face significant challenges ahead. Although the banking system exhibits a modest degree of sensitivity to interest rate risk, the high percentage of loans in foreign currency raises the concern that banks may be vulnerable to the impact of the indirect credit risk of a lek depreciation. However, with loans still a small proportion of assets and net overall long positions in foreign exchange, few Albanian banks suffer serious capital deterioration when foreign exchange rates move. Ongoing assessments of vulnerabilities are advised, however, given the rapidity with which the banking sector is changing.

Other sectors of the Albanian financial system are not large enough to be systemically important, but growth in the insurance sector is quite rapid and problems in the sector may undermine growing confidence in financial institutions more generally. A combination of poor internal governance, weak financial accounting and reporting practices, and a regulator that is still considered to be technically rather weak could lead to additional risk-taking by insurance companies. The limited set of investment opportunities for insurance companies - namely government securities and real estate - constrain diversification of assets and contribute to concerns.

Overall, development of the financial sector is hindered by a number of institutional weaknesses - ranging from inadequate land registration and titling systems to the absence of proper accounting standards. Money laundering and corruption, the latter perceived to be a particular problem in the judicial system, are two areas that will require strong political resolve. The authorities need to assure the basic structure for contract enforcement, which will in turn permit the trust and confidence needed for counterparties (be they banks, non-bank financial institutions, foreign exchange bureaus or average citizens) to trade with each other.

Banking supervision under the central bank, the Bank of Albania (BoA), has been strengthened considerably in recent years, as conformity with most of the Basel Core Principles demonstrates, but other supervisory structures are weak by comparison. For a very small financial system, Albania has too many financial sector regulatory entities, some of whom have no market participants to regulate. In view of the scarcity of qualified and skilled financial sector professionals, regulatory efficiency could be enhanced by merging the insurance, pension, and securities supervisors into one body as a first step and re-examining integration with banking supervision at a later stage.

Box 1 summarizes the main recommendations to strengthen financial sector stability stemming from the FSAP. 


\section{Box 1. Albania: Key FSAP Recommendations}

\section{Short-term}

- $\quad$ Pursue efforts to increase the awareness of consumers and other bank borrowers of the risks inherent in foreign currency borrowing, by encouraging or requiring banks to discuss exchange rate risks explicitly with borrowers before contracts are signed.

- Discuss with banks means of assessing the risks arising from foreign currency denominated loans and adjust existing loan classification schemes or provisioning if warranted.

- $\quad$ Facilitate the creation of a well-functioning credit bureau under the leadership of BoA.

- $\quad$ Undertake review of bank exit/receivership provisions and contingency planning arrangements, using "emergency bank failure scenarios" to assure readiness for such eventualities.

- $\quad$ Proceed with the plans to revise AML law in line with the FATF Recommendations 2003.

- $\quad$ Offer the Albanian Securities Exchange (ASE) to the private financial sector for a nominal amount to own and operate; failing that, close down the idle ASE.

- Improve institutional capacity for public debt management by clearly articulating the objectives, strategies, and decision-making processes for public debt management.

- Include senior qualified and experienced finance professionals in the leadership of the Insurance Supervisory Authority (ISA) both at the supervisory board level and management with adequate remuneration.

\section{Medium term}

- $\quad$ Begin integration of insurance, securities, and pension fund regulatory bodies into an integrated nonbanking regulator; consider feasibility of integrating banking supervision at a later stage.

- Improve land registration, titling systems, and judicial procedures for collateral enforcement.

- $\quad$ Ensure effective implementation of proper accounting standards.

- $\quad$ Increase capacity of the financial intelligence unit (FIU) to deal with money laundering.

- $\quad$ Issue and enforce insurance sector prudential regulations in line with international standards.

- $\quad$ Encourage bottom up consolidation or pooling of resources of credit and savings unions.

- Harmonize and enhance regulation governing various credit unions and consider introduction of a separate deposit insurance for these institutions. 


\section{Macroeconomic EnVIRonMent}

1. The macroeconomic situation is stable and poses only moderate risks to the financial system. Output growth has averaged about 7 percent in 1999-2004, consumer inflation has generally stayed between 2-4 percent, and the public debt to GDP ratio has trended down to $55 \frac{1}{2}$ percent at the end of 2004 . Barring any significant change in the overall environment growth is expected to remain at around 6 percent over the medium term. The domestic currency, the lek, has continued to appreciate in response to rising external inflows, improved confidence, favorable yields on lek assets, and a portfolio shift of residents' net wealth from foreign to domestic sources.

2. Though overall economic growth has been strong, the lack of a self-sustaining export-driven component leaves the economy vulnerable to large trade and current account deficits, some 20 percent and 6 percent of GDP respectively, and to a dependency on migrant remittances as a source of external financing. Though quite stable to date, dependence on remittances is a potential source of risk - both because it funds a significant portion of consumption and investment expenditure and because a reduced supply of foreign exchange entering the country could lead to downward pressure on the exchange rate. A decrease in demand from the key sectors financed with remittances - such as construction, trade and services - which together account for half the economic growth in 2004 could directly affect growth. The quality of banks' loan portfolios could deteriorate from slower growth or exchange rate changes that raise indirect credit risks.

\section{Monetary Policy And LiQuidity Management}

3. The BoA is solely responsible for conducting monetary policy with the primary objective to achieve and maintain price stability, and for foreign exchange policy. The practical approach has been to aim toward an annual inflation rate within a range of 2 to 4 percent. With respect to foreign exchange, the BoA has adopted a fully flexible exchange rate regime, where the exchange rate is primarily determined by market forces. Nevertheless the BoA intervenes to smooth foreign exchange rates when the currency appears excessively volatile or unrelated to economic fundamentals.

4. The policy instruments used to conduct monetary policy operations are adequate and contribute to the resilience of the financial system. Open market operations, which include repurchase agreements (repos), reverse repos, and outright transactions, have helped the authorities to achieve their operational targets and manage banks' liquidity. Interventions are in general transparent with clear rules for counterparty participation, except in the area of foreign exchange interventions where BoA procedures and selection criteria are being clarified (Box 2). Reserve requirements, which are remunerated and uniformly set at 10 percent of deposits and averaged, are consistent with good liquidity infrastructure. 
Box 2. Albania: Transparency of Monetary Policy

The BoA demonstrates an overall satisfactory degree of transparency with regard to the formulation and reporting of monetary policy decisions and operation, though some weaknesses in BoA public communication strategy and public accountability remain. Public availability of information on monetary policy has greatly improved with the publication of periodic reports and disclosures. Rules and procedures for conducting BoA foreign exchange interventions in the domestic market will be finalized and publicly released shortly. Public accountability has improved with externally audited BoA financial statements and disclosure of internal governance procedures, but the latter need to be further strengthened. The lack of general awareness regarding the role of the BoA as a fiscal agent for the government potentially hinders independence. Communication with the public remains inconsistent and needs to be part of an overall communication strategy.

Suggestions for improving BoA transparency and its conduct of monetary policy include:

- Establish a separate Monetary Policy Committee made up of qualified members in which only monetary policy discussions and decisions would be taken;

- Facilitate communication with the public by creating a specialized unit responsible for designing and implementing a monetary policy communication strategy and establishing regular meetings with market participants;

- Remove potential doubts about BoA independence by disclosing the rules and procedures of the BoA role as fiscal agent in government debt issuances and the costs incurred thereby; and

- Establish explicit internal control and oversight mechanisms; strengthen code of conduct standards for BoA board members; and disclose the rules and procedures behind the foreign exchange market operations in the domestic market.

5. The main vulnerabilities to managing liquidity in the banking system, and thus the efficiency with which monetary policy goals are reached, include a weak interbank market and a shallow domestic foreign exchange market. Currently the banking system is overly liquid due to a lack of lending opportunities and a continuous inflow of deposits that can be used to purchase safe, and higher yielding, government securities. An active interbank money market will develop as the financial system matures and banks find they have insufficient funds to lend. There is no specific institutional impediment to the development of an interbank market and rates charged by the BoA are typically less advantageous than those on the overnight interbank market, although the comparison is difficult given the dearth of transactions to examine. The BoA should continue to assure it offers less advantageous rates 
and provide the banks with support for developing contracts (perhaps standardized) among themselves to build the confidence necessary to engage in interbank trading.

6. Though there is an adequate supply of underlying government securities used to conduct monetary policy, government debt holdings are highly concentrated and the market conditions have raised questions about the validity of prices. Reducing the concentration of the investor base is one of the most important public debt challenges in Albania. Commercial banks hold about three-quarters of all Treasury bills and notes. Even within the banking system the holdings are highly concentrated with the newly privatelyowned Raiffeisen bank holding nearly half of the outstandings. Since such government debt is issued in domestic currency, barring an outright default, which is unlikely, banks mostly stand to benefit from fiscal difficulties as maturities are short-term and yields would rise. ${ }^{1}$

7. The retail channel needs to be nurtured since it represents the only nonbank source of demand for government securities in the near future. Other institutional investors are still rather small, holding only about 2 percent of outstanding government debt. To encourage retail demand, the BoA should keep its retail auction window open and upgrade its processes to allow efficient handling of individuals' participation. Currently, insufficient technical capacity have impaired the functioning of the retail window. The BoA should charge for its services as the issuer of government securities. A fee paid by retail Tbill purchasers would allow the BoA to upgrade its system to accommodate growing retail demand.

8. The apparent shallowness of the formal foreign exchange market makes the financial system subject to a potential foreign exchange liquidity shock, but this vulnerability is mitigated by several factors. Banks maintain relatively small net open foreign exchange positions in the context of a fairly well-designed prudential oversight framework. Also, banks hold large foreign exchange assets abroad that could quickly be brought onshore. In addition, banks are required to hold reserves on foreign currency deposits in foreign currency, which provides a liquidity cushion against large deposit withdrawals. Finally, the BoA holds a satisfactory level of net international reserves, which should allow it to address a liquidity shock of a reasonable magnitude. The depth of the market will be enhanced by developing trust among the parties, including through the transparent publication of the procedures use by the BoA in choosing its counterparties.

\footnotetext{
${ }^{1}$ See sovereign debt sustainability analysis, Appendix IV in Country Report No. 05/89.
} 


\title{
III. Macroprudential Analysis Of Risks to FinAnCial Stability
}

\author{
A. Banks
}

\section{Overview and Performance}

9. The Albanian banking sector dominates the financial sector with over 90 percent of all financial intermediaries' assets. The banking system consists of 17 banks (2 Albanian and 15 foreign-owned/or joint ventures) with assets as of end-2004 amounting to some 52 percent of GDP. In April 2004, the government sold its stake in the largest (savings) bank to Austrian-based Raiffeisen, resulting in about 50 percent of the banking system assets moving from public to private hands, leaving a large dominant bank, 5 to 6 medium-sized banks, and a remaining set of small, niche banks. The savings bank, prior to privatization, was prohibited from lending, and held some 70 percent of the outstanding T-bills as its primary asset, but has declared its intention to develop a loan portfolio.

10. The banking system is highly liquid, with liquid assets at a high $\mathbf{7 5}$ percent of total assets, owing largely to a lack of lending opportunities and relatively high and safe returns on government securities. No specific liquidity ratio is imposed by banking supervisors, though regulations require banks to establish a liquidity management policy, and contingency plans, to deal with any adverse developments threatening the bank's liquidity. Banks do not need to raise deposit rates in order to attract more deposits and can earn favorable spreads by purchasing government T-bills. This situation can be observed in the low loans-to-GDP ratio-bank credit to the private sector (excluding state-owned enterprises) accounts for about 101/2 percent of GDP as of end-April 2005-the lowest in central and eastern Europe. The low loan/asset ratio (14.6 percent) is primarily because Raiffeisen has negligible loans but even without Raiffeisen the ratio is only 28.4 percent. Of the total assets in the banking system 76 percent are held in government securities (Table 1).

11. The Albanian banking system has much of its assets (about 38 percent) and loans (nearly 83 percent) denominated in foreign currency, principally the euro and U.S. dollar. Other assets are mostly euro market placements and euro market securities from well-rated sovereigns and international financial institutions thus balancing their foreign currency deposits. There is generally a high demand for foreign currency loans, though this varies across banks. Some banks report that borrowers simply note that interest rates applied to foreign currency denominated loans are lower than in lek and ignore the foreign exchange risk they are assuming despite information about risks provided by the banks. Some banks attempt to match foreign exchange deposits with loans closely, while others transform lek deposits into foreign currency to meet demands for foreign currency denominated loans. Nonetheless, banks maintain net open foreign exchange positions well within the prescribed limit of 20 to 30 percent of regulatory capital (8.7 percent as of end-April). 
Table 1. Albania: Aggregate Balance Sheet of Banks (in percent of assets)

\begin{tabular}{|c|c|c|c|c|}
\hline & 2002 & 2003 & 2004 & 2005-Q1 \\
\hline \multicolumn{5}{|l|}{ Assets } \\
\hline Treasury and interbank transactions & 80.6 & 76.5 & 72.4 & 69.7 \\
\hline Cash & 2.0 & 2.0 & 2.3 & 2.0 \\
\hline Transactions with central bank & 8.7 & 8.7 & 8.7 & 8.5 \\
\hline of which; required reserves & 7.8 & 8.4 & 8.3 & 8.4 \\
\hline Treasury bills & 51.6 & 49.6 & 45.8 & 44.5 \\
\hline Transactions with banks and other Fis & 18.3 & 16.2 & 15.6 & 14.7 \\
\hline Operations with customers (gross) & 11.4 & 13.5 & 16.4 & 17.5 \\
\hline Loans to private sector and households & 10.9 & 12.8 & 15.2 & 16.1 \\
\hline of which: real estate loans & 1.9 & 2.1 & 2.5 & 2.5 \\
\hline Securities transactions & 5.0 & 5.4 & 7.0 & 8.9 \\
\hline Provisions & -0.3 & -0.4 & -0.5 & -0.4 \\
\hline Other assets & 3.3 & 4.9 & 4.7 & 4.3 \\
\hline \multicolumn{5}{|l|}{ Liabilities } \\
\hline Treasury and interbank transactions & 5.3 & 4.4 & 4.5 & 4.3 \\
\hline of which: Deposits from banks and other FIs & 3.1 & 3.1 & 2.9 & 2.8 \\
\hline Operations with customers & 84.0 & 87.5 & 87.0 & 86.9 \\
\hline Public administration & 1.3 & 0.9 & 0.7 & 0.7 \\
\hline Private sector & 82.7 & 86.5 & 86.4 & 86.2 \\
\hline of which: current accounts & 10.7 & 10.1 & 10.7 & 11.8 \\
\hline demand deposits & 2.8 & 3.0 & 5.5 & 5.7 \\
\hline time deposits & 67.1 & 71.2 & 68.4 & 66.9 \\
\hline Other liabilities & 4.0 & 2.0 & 2.2 & 2.6 \\
\hline Permanent resource & 6.7 & 6.2 & 6.3 & 6.2 \\
\hline Of which: shareholder equity & 6.4 & 5.9 & 6.1 & 5.8 \\
\hline Memorandum: Foreign currency assets & 37.5 & 36.3 & 37.4 & 38.6 \\
\hline Total assets/liabilities (in millions of Lek) & $339,304.98$ & $373,634.54$ & $426,440.00$ & $454,919.00$ \\
\hline
\end{tabular}

12. Overall, while the Albanian banking sector has demonstrated relatively good performance in recent years, with high levels of earnings and capitalization and a low level of classified or non-performing assets, accelerating credit growth may become a drag on performance in the future. The regulatory capital/risk-weighted asset ratios (CARs) have stayed at high average levels, above 20 percent in recent years, mainly as a 
result of the high concentration in zero risk weighted T-bills (Table 2). ${ }^{2}$ All banks maintain strong capital positions, with CARs ranging from around 15 percent for the most active lenders to over 200 percent for some small banks. Average profitability is strong with the return on assets of 1.2 to 1.4 percent in recent years, while return on equity has varied tightly around 20 percent. With the removal of bad loans from state banks, aggregate NPL ratios have declined substantially over the years from over 33 percent in 2000 to less than 5 percent, with about half of bad loans concentrated in one lender. The three largest lending banks, which account for about half of the loan market, have sustained good loan quality.

Table 2. Albania: Financial Soundness Indicators

\begin{tabular}{|c|c|c|c|c|c|c|c|c|}
\hline & \multirow[b]{2}{*}{2002} & \multirow[b]{2}{*}{2003} & \multicolumn{4}{|c|}{2004} & \multicolumn{2}{|c|}{2005} \\
\hline & & & Mar. & Jun. & Sep. & $\overline{\text { Dec. }}$ & Mar. & Apr. \\
\hline Regulatory capital to risk-weighted assets 1 / & 31.6 & 28.5 & 30.1 & 27.0 & 25.1 & 21.6 & 21.0 & 20.8 \\
\hline Regulatory Tier 1 capital to risk-weighted assets 1 / & 32.9 & 29.0 & 30.3 & 26.1 & 24.8 & 21.5 & 20.4 & 20.3 \\
\hline Nonperforming loans net of provisions to capital & 4.8 & 3.9 & 2.7 & 2.4 & 3.4 & 3.8 & 3.9 & 3.0 \\
\hline Nonperforming loans net of provisions to total gross loans & 5.6 & 4.6 & 4.7 & 4.3 & 4.7 & 4.2 & 3.5 & 2.8 \\
\hline Return on assets & 1.2 & 1.2 & 1.3 & 1.3 & 1.4 & 1.3 & 1.3 & 1.3 \\
\hline Return on equity & 19.1 & 19.5 & 21.1 & 22.2 & 23.7 & 21.1 & 22.1 & 22.5 \\
\hline Interest margin to gross income & 87 & 89.6 & 88.3 & 85.7 & 87.1 & 80.3 & 83.2 & 82.5 \\
\hline Noninterest expenses to gross income & 64 & 57.4 & 60.4 & 62.4 & 61.2 & 66.2 & 81.5 & 82.3 \\
\hline Liquid assets to total assets & 77.9 & 73.6 & 74.1 & 73.2 & 73.5 & 71.1 & 70.3 & 69.4 \\
\hline Liquid assets to short-term liabilities & 120.8 & 109.5 & 115.5 & 114.2 & 120.7 & $\ldots$ & 83.2 & 85.0 \\
\hline Net open position in foreign exchange to regulatory capital & 2.7 & 7.3 & 5.1 & 9.6 & 16.4 & 7.4 & 3.5 & 8.7 \\
\hline
\end{tabular}

Source: Data provided by Bank of Albania.

1/ For April 2005, the value for risk-weighted assets used in the calculation is the value at March 2005, as risk-weighted assets are only reported by banks on a quarterly basis.

\section{Vulnerabilities in the Albanian Banking System}

13. Structural characteristics (especially, but not limited to, the privatization of the dominant bank) complicate the risk environment that the banking system faces. Albania is a highly dollarized financial system, with the lek, euro and the U.S. dollar all having significant shares of assets and liabilities. Stress tests conducted (below) explored the sensitivity of the system to various shifts in exchange rates and interest rate yield curves for the different currencies. A more difficult task is to examine the effects of the entrance of Raiffeisen since banking competition is likely to change rapidly and the potential size of changes is unknown.

\footnotetext{
${ }^{2}$ If T-bills are considered higher risk (a 50 percent risk weight) CARs decrease to 11.8 percent, barely below the 12 percent minimum.
} 
14. Most banks in Albania expect the entrance of Raiffeisen to put downward pressure on lending spreads as banks attempt to compete for borrowers. Admittedly, from the customers' view, increased competition will mean lower fees and borrowing costs and, in principle, a more efficient banking sector. However, if a spurt in credit growth were associated with lower lending standards it could lead to higher non-performing loans and a consequent effect on profitability and CARs leading, ultimately, to a weakened banking system. Credit growth has accelerated to 50 percent (y-o-y) in April 2005 and is some 65 percent higher than two years ago. And while the sectoral distribution of credit is broadbased and balanced, the chances of a damaging credit boom arising are enhanced by the lack of financial information available on potential borrowers. In many cases, loans are made on the basis of incomplete and, potentially inaccurate, information. In the area of corporate lending, firms balance sheets and income statements may be altered to avoid taxes. In the case of individuals, the information about remittance income (often the source of foreign exchange for loan payments) is sketchy and unverifiable, though it has been stable to date. Thus, supervisors and banks should pursue efforts now to make borrowers aware of the risks inherent in foreign currency denominated loans and assure themselves that adequate capital is held against potential loan losses.

15. Another risk associated with a spurt in credit growth is simply an inability of banks to process the loans in a timely manner, leading to mis-estimations of liquidity needs and errors in documentation and recording. Variability in system-wide liquidity needs could present various problems not anticipated during a period of excess liquidity. Customers may become disillusioned with banking services if errors are made.

16. The robust economic environment and rising real estate prices are also encouraging lending, particularly in new longer-term products. Real estate lending is, as yet, not a large share of lending for banks (only 2.5 percent of outstanding loans) as most housing in Albania appears to have been purchased with cash. Fundamentally, the stock of housing in Albania is below standard and there appears to be natural pent-up demand for better housing. That said, the terms of mortgage loans have not settled on uniform standards, with most (currently) denominated in euro. Some banks are extending the maturities of these loans as far out as 20 years (far beyond the average 2-year maturity) at interest rates that may or may not compensate appropriately for risk.

17. Since 95 percent of collateral consists of real estate, large increases in collateral values as real estate prices rise could lead to an over-extension of credit and efforts to collect price data and gauge the degree of speculative activity is warranted. Although there are no prescribed loan-to-value ratios in Albania, it is typical for collateral to cover over 120-140 percent of the loan and (to date) has led to the low level of credit provision. But, if the real estate market becomes more speculative and more leveraged through bank loans, a decline in demand can cause a fall in real estate prices and a contraction in the construction industry. Thus, collateral may fall in value, and simultaneously the ability of borrowers to pay may decline. Moreover, the ability of banks to obtain the value of the collateral in the event of non-performance of a loan is still difficult and expensive. 


\section{Stress tests}

18. Overall, the stress tests indicate that the banking sector appears to be fairly resilient to hypothetical shocks to foreign exchange, risk, interest rate risks and credit risks without causing systemic distress. Underlying profitability provides a buffer to absorb negative shocks before they deplete regulatory capital. As interest rates on government securities decline, profits will be squeezed and pressures for consolidation will intensify. Increased competition from the privatization of the largest bank has the potential to put significant downward pressure on bank incomes, although since the stress tests were initiated the changes have been gradual, with Raiffeisen unable to increase is loan book quickly.

19. With regards to direct foreign exchange risk, the banking system does not suffer from serious deterioration of their CAR from various foreign exchange shocks (Table 3). Foreign exchange volatility has moderated substantially over time, so a maximum shock of 20 percent against all currencies (and separately against the dollar and euro) was used. Generally, the system benefits from a lek depreciation and loses from a lek appreciation, since it is long in foreign exchange. The effect is, however, less favorable in the case of the euro, since most banks are aided by the fact that their capital is denominated in dollars. Only for the shock involving a lek depreciation against the euro do any banks show significant CAR declines, and these occur for small highly capitalized banks that can readily absorb them. In the case of the lek appreciation, no bank winds up with a post-shock CAR below 11 percent.

20. The banking system is also fairly resilient to direct or indirect credit risks in spite of the large part of the loan portfolio denominated in foreign currencies owing to the low base for lending and offsetting positions. The test assumes a very large lek depreciation shock (30 percent) and associates with it a large NPL shock-10 percent of standard foreign currency loans deteriorate to lower loan classes. The gains on the appreciation of the open position offset losses from increased NPLs for the system as a whole, so that the overall CAR declines by only about half a percentage point as compared to nearly 2 percentage points for a 10 percent deterioration in credit quality for all standard loans. A few banks, however, do suffer from marginally lower post-shock CARs in the depreciation with indirect credit risk case than in the simple NPL shock. This outcome arises because remaining foreign currency loans require increased provisioning. In this case, two banks slip below the 12 percent required CAR.

21. The Albanian banking system exhibits a larger degree of sensitivity to interest rate risk given the current bank balance sheet configurations than to credit risks. A 5 percentage point upward shift in yield curve, corresponding to a 3 standard deviation change in the Albanian T-bill rate for a one-year horizon, was used in all cases. Even in the case of a 5 percentage point shift in all yield curves, the net systemic effect is limited relative to preshock CARs or income. In no case does the CAR of any bank fall below 11 percent. 
Table 3. Albania: Effects of Stress Tests on the Banking System (in percentage points)

\title{
Sensitivity tests ${ }^{1}$
}

Exchange rates

\author{
Effect on system CAR Effect on system ROA
}
20 percent lek depreciation ${ }^{2 /}$
20 percent lek appreciation
20 percent USD depreciation
20 percent USD appreciation
20 percent Euro appreciation
30 percent lek depreciation with indirect credit risk $^{3 /}$

$\begin{array}{lr}+1.72 & +.06 \\ -2.31 & -.06 \\ -2.63 & -.06 \\ +2.30 & +.05 \\ -0.21 & 0.0 \\ & \\ -0.48 & -.36\end{array}$

Interest rates

5 percentage point rise in lek yield curve

5 percentage point rise in USD yield curve

5 percentage point rise in Euro yield curve

NPLs

10 percent deterioration in standard loans

\section{Competitiveness shock scenario $^{4 /}$}

$5 \mathrm{pp}$ fall in loan spreads; 3 pp rise in T-bill rates

$5 \mathrm{pp}$ fall in loan spreads; no change in T-bill rates

\footnotetext{
${ }^{1 /}$ Stress tests conducted for values as of end-September 2004.

${ }^{2 /}$ Against all currencies on banks' balance sheets.

${ }^{3 /}$ Indirect credit risk is calibrated as a 10 percent deterioration of standard foreign currency loans to lower loan classes, provisioned at the prevailing average rate, combined with a re-classification of remaining standard loans to Class 2 (special mention), provisioned at 5 percent.

${ }^{4 /}$ Based on following assumptions:

Existing total loans grow 35 percent.

Raiffeisen Bank (RB) loans increase to Euro 100 million (lek 12.5 billion), as per RB plan.

Other banks grow loans proportionally at 15.17 percent.

All RB loan growth is offset by T-bill declines; RB portfolio size is unchanged.

Other banks absorb old T-bills proportionally; new T-bills absorbed by all banks in proportion to immediate post-shift shares; new T-bill issuance is 23,412 lek billion, projected net new borrowing.
} 


\section{The Albanian banking system is somewhat sensitive to the unique} "competitiveness risk" emerging from the recent entry of Raiffeisen and a new type of stress test is designed to examine this risk. Raiffeisen's announced plan to grow its loan book which may be accompanied by a gradual shift out of T-Bills raises a risk of a competitive squeeze in loan yields and a simultaneous rise in T-Bill yields in the wake of reduced demands. A "competitiveness" shock scenario of a 5 percentage point drop in loan spreads and an instantaneous 3 percentage point increase in TB rates showed a negative impact on the ROAs if new to-be-issued T-Bill rates do not rise as indicated by a fall of around 80 basis point in the ROA. Higher newly auctioned T-Bill rates generate additional income that more than offsets the earning losses that are likely to arise from a competitive squeeze on margins leading to an improvement in the ROA of nearly 50 basis points.

However, the stress tests all rely on existing balance sheet positions, which are likely to change going forward, and thus the relatively benign results should not be relied upon exclusively to assure smooth adjustments.

\section{B. Nonbank Financial Institution}

\section{The nonbank sector remains relatively small and is not current a source of} systemic vulnerability. The small size of nonbank financial institutions is consequence of its early stage of development, the lack of understanding of financial products and services by potential users, and the still rudimentary level of basic financial infrastructure. The enterprise sector consists mostly small firms (91 percent of enterprises have 1-4 employees) that extensively use of internal funds (e.g., informal, family-generated finance, usually stemming from remittances) and have little direct access to foreign currency borrowing from abroad. The lack of sufficient or reliable financial data, and virtually no formal financial reporting implies the development of nonbank financial entities will take time. ${ }^{3}$ Steps to address many of the institutional impediments are being undertaken and the FSAP provided a prioritized list of items to help improve nonbank financial intermediaries.

\section{Insurance companies}

24. Though the authorities have made significant efforts to improve the Albanian insurance industry, it is, as yet, small and fragile. The insurance sector in Albania is very underdeveloped relative to its potential, and compared to those in other south eastern European countries. ${ }^{4}$ Total premium income represents only 0.5 percent of GDP and total assets about 1 percent of GDP. That said, total premium income has increased nearly $2 \frac{1}{2}$ times between 1999 and 2004 and during 2004 the number of insurance companies doubled from 5 to 10 .

\footnotetext{
${ }^{3}$ Though no explicit data is available, the net open foreign currency position of the non-bank private sector-proxied by foreign currency deposits less foreign currency loans--has been falling since early 2003 and is now about $63 / 4$ percent of GDP.

${ }^{4}$ The premium per capita in Albania is $\$ 9.80$; the next highest country in the region is Romania at $\$ 35.80$.
} 
25. Insurance companies are fiercely competing for market share in their main line of business, motor vehicle insurance, and may increasingly take less prudent risks. Excessive premium discounting may lead to low solvency margins, increasing the risk of non-payment of claims. Even though the premiums are required by law to remain within a range and despite administrative sanctions by the insurance regulator, companies apparently fail to comply with the law. While all legitimate competition is welcome, prudential standards need to be monitored and strictly enforced to avoid company failures and resulting loss of public confidence that may hinder development of long-term savings institutions.

26. A new updated insurance law has been recently enacted and some secondary regulations are being written, but the critical areas of financial reporting, governance, transparency and asset valuation are not yet up to international standards. Now that new licensing criteria has been established, the Insurance Supervisory Authority (ISA) can ensure only high quality companies enter the insurance business and deficient ones exit. Given the lack of asset choices available to insurance companies - namely, government securities and real estate - attention to prudential norms and asset valuation will be critical.

\section{Pension funds}

27. Efforts to assure the necessary prudential framework for a private, voluntary funded pension scheme ('third pillar') need to be accelerated. Key strategic issues (e.g. take-up potential, cost-efficiency of operational arrangements, safeguards, and impact on the financial system) need to be addressed before the legal framework for a third pillar is finalized. Given the significant weaknesses in the current law for pension funds related to licensing criteria, supervision, governance and profit-sharing arrangements, investment regulations and eligibility for benefits, there may be need for a new law. Albania would benefit from a well-articulated strategy to develop the entire pension system, including actuarial studies assessing the long-term sustainability of the public pension system (the "first pillar").

\section{Savings and Credit Unions}

28. Although their assets amount to less than 1 percent of GDP, Albania's network of savings and credit union associations (SCAs) and micro-credit institutions have grown rapidly, with assets doubling in the last two years. Over the last decade these institutions have successfully serviced about 100,000 urban and rural individuals - and the demands from the members for more financial services have increased.

29. Since a reduction in donor support is expected as many financial programs reach their conclusion, future growth of credit unions will depend on their ability to mobilize additional capital and funding resources, pool resources, and carry out necessary institutional transformation. The underlying principle behind the donors' technical and financial support has been to kick start development of successful micro finance institutions in Albania and support them until such time that they are able to function as financially and operationally autonomous intermediaries. While over the medium-term 
horizon, donor support could continue to play a positive role, increasing demands and expectations for larger loans and a wider variety of financial services implies that these institutions now need to grow beyond their pure dependence on government or donor support.

30. Consolidation into larger credit unions would be a viable method to be able to offer larger loans and provide more banking-like services. There are already reports of individual credit unions planning to merge to achieve a larger critical mass for financing larger processing plants, warehousing, cold storage or marketing organizations. There is also a recent proposal to convert one micro-credit institution (the Mountain Area Finance Fund, MAFF) into a rural cooperative bank. The government should aim to eliminate its entire equity role in MAFF to assure the new MAFF does not become a publicly-owned or controlled institution. Moreover, MAFF should not be restricted to agricultural lending but service all rural clients if it is to avoid an inadequately diversified loan portfolio. Generally, it will be useful for all the credit unions and micro credit institutions to explore the possibility of pooling their resources into a larger cooperative institution. This need not imply the benefits of local ownership are given up, but that human and financial resources be shared.

\section{Securities markets}

31. Securities markets are not a likely source of finance for private enterprises in Albania in the near future. ${ }^{\mathbf{5}}$ The Albanian Stock Exchange (ASE), established in 1997, has had no listings and no trading over the last eight years. It has been funded over the years from the state budget in the hope that, either some of the state owned enterprises (SOEs) will be privatized through the ASE leading to the development of equity securities trading, or a secondary market in government securities will develop through the exchange leading to a corporate debt securities market. This has not materialized, partly because Albanian enterprises are rather small and the SOEs have been primarily sold to strategic investors rather than the general public and are therefore closely held. Larger companies have access to funding either internally or externally. As a result, financial market participants in Albania have displayed no appetite to develop the ASE. The Albanian government should seriously consider offering the ASE to private financial entities if they are interested, and failing that the ASE should be allowed to close down for want of activity.

\section{Publicly-traded securities will likely develop when the institutional} underpinnings improve and the enterprise sector requires arms-length financing. Albania's information constraints, a weak collateral and contract enforcement regime, and the absence of effective property registers hinders the development of corporate bond and equities markets. The lack of sufficient, reliable and timely data prevents any assessment of enterprise sector performance or risks. Key private sector developmental obstacles continue

\footnotetext{
${ }^{5}$ Given the nearly non-existent securities markets a formal ROSC covering the IOSCO Core Principles was not performed.
} 
to persist including reform of tax administration and the judicial system. Land registration and titling are still in early stages limiting effective use of land as collateral.

33. The infrastructure of the Albanian financial system would therefore greatly benefit from a well-functioning credit bureau, which would provide access for financial intermediaries to borrower data. There have been attempts during the last few years to set up such a bureau since most commercial banks support the idea, but the initiatives have remained dormant due to competitive concerns regarding customer data sharing. The BoA should therefore take the lead, with a view of its transfer to a private operator in the future.

\section{Strengths and Vulnerabilities: the Financial Stability Policy FRAMEWORK}

\section{A. The Regulatory and Supervisory Framework}

\section{A number of actions have been taken to strengthen the regulatory and} supervisory framework in recent years with many of the resources focused on banking supervision, as compliance with most of the Basel Core Principles demonstrates. With the help of technical assistance from the World Bank and the IMF, the banking supervision department in the BoA has upgraded its technical capacity and operating practices. The supervisory team has been properly trained and appears competent in following international best practices, even though experience in managing difficult enforcement challenges under stressful situations is still limited. Continuity of the skilled staff in the medium term will be necessary for the development of internal depth and breadth of experience in the supervision department.

35. BoA banking supervisors have powers to set prudential regulations and the rules themselves are comprehensive but some amendments are still needed to bring the BoA up to international standards. Activities permitted by banks are clearly defined, and the licensing criteria are comprehensive and administered effectively. Capital requirements and rules governing credit exposures are subject to adequate supervision although the market is subject to poor disclosure by borrowers. Supervisory examinations and offsite analysis procedures are well developed and the supervisors effectively implement the corrective measures available to them. Subject to some amendment of the law, the BoA has adequate powers of enforcement. Though Albanian banks have no foreign or domestic subsidiaries yet, many of Albania's banks are branches or subsidiaries of foreign banks and even though they have bank licenses in Albania, the BoA will need to continue to seek improved relationships with home authorities and assess their capacity to practice effective consolidated supervision. With its relatively good reputation, recent pressure to move salaries of BoA employees toward the general civil service pay scale should be strongly resisted.

36. The BoA also supervises credit unions and micro-credit institutions, which have different legal frameworks as well as different licensing and supervision requirements. Progress has been made to strengthen the BoA's supervisory capacity and further improvement of prudential norms for credit unions is underway. Micro-credit institutions 
have a different legal status and therefore different licensing or supervisory requirements. To the extent that credit unions and micro-credit institutions become more "bank-like" (including benefiting from deposit insurance) so too will their supervisory oversight need to become more rigorous.

\section{The Insurance Supervision Authority (ISA) responsible for the supervision of} insurance companies has recently been restructured, but still lacks sufficient technical expertise and will need close attention before it can become an effective supervisory entity. Political support and technical assistance will be necessary to upgrade the technical knowledge, skills, and training of management and operating staff in the ISA, both in development of proper prudential regulations, and in implementation and enforcement practices. In order to attract and retain high quality insurance professionals their remuneration should be closer to market levels. Establishing the independence and credibility of the ISA is an important priority, which will depend on the ISA's ability to ensure the consistent and fair enforcement of laws and regulations.

38. For a very small financial system, Albania has too many financial sector regulatory entities, some of whom have no market participants to regulate. This has led to a fragmentation of authority and responsibility, a drain on budgetary resources, and inefficient use of scarce regulatory and supervisory skills. There are four separate regulatory bodies: banking (BoA) (which oversees credit unions, foreign exchange bureaus, and nonbank financial intermediaries), insurance (ISA), securities (ASC) and private pension funds (OIPISP), of which the last two have no securities market participants or private pension funds to regulate and supervise. While it would definitely enhance the credibility of insurance sector supervision, for instance, to integrate it with the BoA, it might distract BoA from solidifying its recent progress. The BoA has managed to attain a high degree of credibility in financial markets and, given the public perception that the insurance supervisor is still very weak, the resources needed by the BoA to assure the same quality of supervision of insurance would likely dilute its mission to oversee banks, precisely when increased vigilance is needed. Thus, at this stage it would be therefore better to begin with integration of all nonbanking regulation and supervision entities in the first stage, and then revisit this issue in a couple of years time.

\section{B. Safety Nets and Liquidity Management}

39. Albania has safety net schemes for bank depositors and some insurance policyholders, but will need to consider the introduction of coverage for the savings deposited in Credit and Savings Associations. The Albanian Deposit Insurance agency (ADI), insuring bank deposits, is quite young and, as such, is still building its asset base. The ADI has not yet needed to pay out claims and while no bank failures appear imminent, the ADI is untested. For insurance, there is a Guarantee Fund that protects these certain types of policyholders (third-party motor vehicle) in a number of cases where payment by the insurer may be withheld or uncertain. For credit unions, the deposits held at the savings and credit schemes of the credit unions are not insured and therefore have no safety nets - these will need to be introduced following further analysis of implementation issues. 
40. While no imminent failure of banks or insurance companies is expected and the legal structure for the exit of distressed banks and insurance companies is in place, it has not yet been tested in practice. Overall, the banking law provides for prompt corrective action for banks as their financial health deteriorates, and for the revocation of the banking license when conditions warrant it. This has not yet occurred and the procedures in place thus remain untested. An emergency preparedness exercise would be useful in light of the potential consolidation and bank exits in the future. Insurance company exits also can occur with the revocation of the license by the Council of the Insurance Supervisory Authority (ISA), the body overseeing the ISA, but no such action has yet been undertaken.

41. In the cases of liquidity crises, the BoA provides lender-of-last-resort facilities to illiquid but solvent institutions through its Lombard credit facility, which generally meets international best practices. The facility was used effectively several years ago when a "run" on the largest savings bank ensued during the parliamentary debate regarding deposit insurance. To help determine quickly whether a bank is eligible for the facility, the Director of the Banking Supervision should be included formally in the decision-making process.

42. The main systemically-important clearing and settlement system, the Albanian Interbank Payment System (AIPS), generally conforms to international standards, but sound electronic retail payments systems are just becoming available. A review of the Core Principles for Systemically Important Payment Systems (CPSIP) shows that the new AIPS is not yet fully compliant with all the core principles, but the system conforms to most of them. A new (retail) inter-bank bulk settlement system, the ACH, was completed July 8 , 2005 and its functioning will need to be evaluated over time. Rapid changes regarding how retail payments take place, such as the growing use of ATM cards and other retail bank checks, challenge the authorities to continuously provide safe and secure payments system. Nonetheless, it is expected that the development of such systems and the mandatory payment of government employees through banks will aid de-dollarization and use of the formal financial system.

\section{Legal ISSUES}

\section{A. Legal Issues}

43. The legal framework governing the regulation and supervision of Albania's financial and non-financial sectors has undergone significant reform over the last decade. The result has been the adoption of a series of laws and regulations that are reasonably comprehensive and broadly consistent with international best practices. However, the implementation and enforcement of the applicable laws has generally been weak, largely as a result of inadequate resources, excessive bureaucracy and corruption, and a low level of respect for the rule of law.

44. From an institutional point of view, the weakest link in the country's financial sector is the judicial system. The courts are perceived by the public as one of the three most corrupt institutions in Albania. Judgments are poorly reasoned and it often prefers a 
particular party irrespective of the merits. The authorities are well aware of these problems and are trying to address them. However, until confidence in the court system has been significantly increased, the country's ability to enforce contracts will significantly limit commercial and financial sector activity.

\section{B. Anti-Money Laundering and Combating the Financing of Terrorism (AML/CFT) ${ }^{6}$}

45. Money laundering continues to be an ongoing problem in Albania, requiring additional resources and stronger political will if it is to be combated effectively. The large informal economy makes it difficult to trace and fight money laundering and potential terrorist financing. However, the degree to which the formal financial sector is involved is, so far, likely to be small given the stringent reporting standards imposed on banks and the ease with which the cash-based informal sector operates. Banking supervisors have instituted the necessary AML/CFT guidelines and enforcement mechanisms are in place. The AML law was revised in 2003, but further improvements are needed. With the assistance of the IMF in late 2004, a newly revised law is now being prepared for parliamentary consideration. Albania recently enacted a law on the financing of terrorism and one to counter organized crime.

46. A financial intelligence unit (FIU) is in place but has insufficient resources to analyze the data it receives. Banks are required to directly report all transactions above a threshold of lek 2 million, including interbank transactions that are unlikely to be linked to money laundering. Given the lack of resources to analyze these reports, a refinement of the types of reported transactions would permit better utilization of existing resources, focusing on suspicious transactions. Banks should be consulted about the most effective means of adjusting the reporting criteria. As well, until the FIU's resources are adequate, recent discussion of lowering the threshold should be postponed as the additional resources would be wasted.

47. The implementation of AML/CFT measures beyond the banking sector is currently limited and appropriate measures need to be put into place. A proposed draft AML law will help to deal with the insurance and nascent securities sectors, other financial institutions, and designated nonfinancial businesses and professions, as defined by the FATF.

\footnotetext{
${ }^{6}$ A full evaluation of the Albanian AML/CFT regime is scheduled for September 2005 by MONEYVAL, the European regional body on the evaluation of AML/CFT measures. As agreed between MONEYVAL and the Bank/Fund, that evaluation will produce a ROSC that will be forwarded to the Boards for information.
} 


\section{Summary ASSESSMents ANd the ObSERVAnCE OF Selected Financial Sector STANDARDS AND CODES}

This annex contains a summary assessment of observance of the Basel Core Principles for Effective Banking Supervision (BCP) and the Core Principles for Systemically Important Payment Systems (CPSIPS) assessments.

The detailed assessment of observance of the Basel Core Principles was undertaken by Gabriella Ferencz (World Bank) and Peter Hayward (retired IMF). The detailed assessment of the observance of the Core Principles for Systemically Important Payment Systems (CPSIPS) was conducted by Massimo Cirasino (World Bank). The assessments were based on the authorities' answers to questionnaires and work during the FSAP mission.

The assessment and updates were based on several sources including:

- a self-assessment of the BCP and CPSIPS by the BoA;

- reviews of relevant legislation, decrees, regulations, policy statements and other documentation;

- detailed interviews with the supervisory authorities;

- meetings with other relevant authorities and independent bodies; and

- meetings with financial sector firms and associations, including banks and financial enterprises.

\section{SUMMARY ASSESSMENT}

\section{BASEl Core Principles For EfFective BANKING SUPERVISION}

\section{General}

48. This assessment of Albania's compliance with the Basel Core Principles for Effective Banking Supervision was carried out by an IMF and World Bank team in the context of a Financial Sector Assessment Program in February 2005, using the methodology recommended by the Basel Committee.

49. The Bank of Albania is the sole supervisory authority for banks operating in Albania. It operates within a supportive framework of banking laws and is empowered to issue regulations which allow for the effective implementation of the banking laws. The banking law is being revised and proposed changes to it will enhance the capacity of the supervisory function to carry out its mandate.

\section{Institutional and macroprudential setting, market structure overview}

50. Banking supervision in Albania is effective, providing the central bank with the means by which to monitor the banking sector as a whole. In addition, individual banks are overseen through a process of periodic offsite analysis and a robust system of onsite supervision. The supervisory authority operates without political interference and is operationally independent functionally as well as within the budget allocations provided for it through the BoA's budget allocation. 
51. The senior staff of supervisors and inspectors is highly knowledgeable and has taken great strides to effectively incorporate best international practices especially in the areas of key risks for Albanian banks. They are knowledgeable about the risks facing the banking sector as a whole and about risks in individual banks and effectively implement the corrective measures available to them. They have been proactive in ensuring that banks institute the needed measures to address money laundering processes.

\section{General preconditions for effective banking supervision}

\section{The banking system}

52. The Albanian banking sector dominates the formal financial sector and consists of 17 banks ( 2 domestically-owned banks and 15 foreign-owned or joint ventures) with assets as of end-2004 amounting to some 52 percent of GDP. In April 2004, the government sold its stake in the largest (savings) bank, placing about 50 percent of the banking system assets in private hands. The system is thus made up of a large, dominant bank, 5 to 6 medium-sized banks, and a remaining set of small, niche banks.

53. The banking system is highly liquid, with liquid assets at a high 75 percent of total assets, in part owing to a lack of lending opportunities and in part owing to the favorable spreads available between deposit rates and banks' large holdings of government T-bills. Overall, the Albanian banking sector has demonstrated strong performance in recent years, with high levels of earnings and capitalization and a low level of classified or nonperforming assets.

\section{The macroeconomic background for the banking sector}

54. The financial sector is exposed to a moderate amount of macroeconomic risk arising from its vulnerability to declining economic growth and adverse interest rate and exchange rate movements. With over 75 percent of the stock of credit built up in the last fourrelatively favorable - years, the banking system's reaction to protracted periods of low growth or exchange rate depreciation has yet to be tested. While a number of factors - such as the current low level of credit provision and the relatively prudent lending policies followed to date - provide a degree of protection, the apparent health of Albanian banks under current conditions cannot be automatically extended to less favorable conditions.

55. Macroeconomic risks appear moderate at the present time. However, banks are forecasting aggressive increases in loan volume over the next year and the vulnerability of the system will likely rise. Rapid credit growth is almost certainly followed by rising loan problems as banks, as well as the economy, cannot efficiently manage or absorb such growth.

\section{The Summary Assessment}

56. The main findings of the assessment of the implementation of the Basel Core Principles are grouped under the following seven main categories of core principles. 
57. Objectives, autonomy, powers, and resources (CP 1): The BoA has clearly defined supervisory objectives and responsibilities and operates within a comprehensive framework of laws and regulations, although the banking law needs updating, which is underway. The BoA has broadly sufficient resources and operates in an environment where it is accountable yet at the same time has operational independence. The legal protection for supervisors needs to be amended to extend the protection to all supervisory and inspection staff, in addition to the administrative level that is currently covered by the law. Information sharing arrangements are in place but need some further refinement. Provisions for the treatment of confidential information are adequate.

58. Licensing and Structure (CPs 2-5): Activities permitted by banks are clearly defined and the licensing criteria are comprehensive and administered effectively. Significant shareholders are vetted but a requirement for additional approval as shareholdings increase their ability to exercise effective control is needed. Additional powers are needed to deal with unauthorized banking business. Limits exist on investment in nonbanking business but supervisory powers should be enhanced to ensure that investments do not exceed the capacity of banks' management abilities.

59. Prudential Regulations and Requirements (BCPs 6-15): The BoA has powers to set prudential regulations and the rules themselves are comprehensive. Although bank structures are presently simple, the BoA needs the power (now planned) to supervise on a consolidated basis. Capital requirements are based on the Basel model with a minimum required risk asset ratio of 12 percent. Credit exposures are subject to adequate supervision although the market is subject to poor disclosure by borrowers and lenders need to rely more on subjective judgment and collateral which is not always easy to realize. Large exposure and connected lending rules are sound but could benefit from the BoA having the power to deem relationships where they are not explicitly covered by the definitions in the law. Other risks are not extensive and are adequately monitored. The BoA supervises corporate governance and internal audit and controls effectively and deficiencies in the anti-money laundering regime are largely outside the scope of the supervisors.

60. Methods of Ongoing Supervision (CPs 16-20): Examination and offsite analysis procedures are well developed and the former at least is well resourced although lacking in experience. External audit is almost entirely done by local offices of major international firms to international standards although more frequent contact with supervisors would be helpful. At present no consolidated supervisory powers exist. This is in the process of being remedied although in practice few consolidation issues have arisen.

61. Information Requirements (CP 21): Accounting standards are in a period of change as banks move over to IFRS which may mean some adaptation of existing supervisory rules on the valuation of assets. More guidance on the valuation of collateral would also be useful.

62. Formal Powers of Supervisors (CP 22): Subject to some amendment of the law, the BoA has adequate powers of enforcement. After the planned changes to the law are agreed 
there will be a need to finalize the revised manual on corrective action also under preparation.

63. Cross-border Banking (CPs 23-25): Albanian banks have no foreign subsidiaries as yet so the absence of consolidated supervisory powers has not been a problem so far. This issue will be resolved with passage of the revised banking law. Many of Albania's banks are, however, branches or subsidiaries of foreign banks and the BoA will need to continue to seek improved relationships with home authorities and develop a capacity to assess their capacity to practice effective consolidated supervision.

Table 4. Albania: Recommended Action Plan to Improve Compliance of the Basel Core Principles

\begin{tabular}{|c|c|}
\hline Reference Principle & Recommended Action \\
\hline CP 1 (2) & $\begin{array}{l}\text { BoA should consider means by which to retain experienced staff to minimize the impact } \\
\text { of turnover; these could include bonuses or other forms of compensation. Offsite } \\
\text { supervision should be strengthened by additional staff given the existing workload and } \\
\text { the increase in the number of licensed banks. The supervisory function in general would } \\
\text { benefit from more staff with legal expertise. }\end{array}$ \\
\hline CP 1 (5) & $\begin{array}{l}\text { The legal coverage and protection of individual supervisors and inspectors performing } \\
\text { their duties, who are not protected in law as are administrators and advisors, should be } \\
\text { incorporated into the draft banking law. }\end{array}$ \\
\hline \begin{tabular}{|l|} 
CP 1 (6) \\
\end{tabular} & $\begin{array}{l}\text { There is a need to clarify the responsibilities of the BoA and the securities commission } \\
\text { with regard to investments and the investment business of banks. }\end{array}$ \\
\hline CP 2 & $\begin{array}{l}\text { The BoA is the legal authority to empowered to address banking activities which are } \\
\text { carried on by unlicensed businesses. Its powers should include the ability to examine } \\
\text { any unlicensed entities engaged in banking business and it should notify other } \\
\text { authorities such as the police and tax authorities of the activity. }\end{array}$ \\
\hline CP 3 & $\begin{array}{l}\text { The evaluation of prospective directors and senior management of banks would benefit } \\
\text { from conversations with those providing references and recommendations. Doing so } \\
\text { would provide more depth to the analysis which is currently performed through a review } \\
\text { of documents. }\end{array}$ \\
\hline CP 5 & $\begin{array}{l}\text { The criteria to judge investments could be expanded to include qualitative judgements by } \\
\text { the BoA of the quality of the proposed investment. The BoA ahould have the authority to } \\
\text { deny a bank's request for approval of an investment if, in its judgement, the bank does not } \\
\text { have adequate financial or organizational resources to handle the acquisition, even if all } \\
\text { other investment criteria are met. } \\
\text { The law or regulation on investments should specify that cases where notification after } \\
\text { the investment is sufficient are only for those activities that are closely related to } \\
\text { banking and the investment is small relative to the bank's capital. The BoA should have } \\
\text { broader authority to approve investments in commercial enterprises as well as to } \\
\text { monitor more closely these investments as part of the ongoing supervision of the bank. } \\
\text { The BoA should have broader authority to be able to receive more than the general } \\
\text { information it currently receives on an annual basis on investments including receipt of } \\
\text { any information it deems necessary given the risks which may exist. }\end{array}$ \\
\hline CP 6 & $\begin{array}{l}\text { Currently the BoA has no powers to apply capital requirements on a consolidated basis. } \\
\text { The authorities are preparing amendments to the banking law which will, if enacted and } \\
\text { applied, remedy this deficiency. }\end{array}$ \\
\hline
\end{tabular}




\begin{tabular}{|c|c|}
\hline Reference Principle & Recommended Action \\
\hline CP 7 & $\begin{array}{l}\text { The supervisory authority should consider requiring banks to provide more training to } \\
\text { their staff in financial analysis, including cash flow analysis. } \\
\text { The supervisor should require that banks have processes and procedures that are } \\
\text { effectively implemented for credits deemed especially risky or not in line with the } \\
\text { mainstream of a bank's activities, i.e, banks should be required to have exception } \\
\text { processing policies and procedures. }\end{array}$ \\
\hline CP 9 & $\begin{array}{l}\text { A more explicit power to group exposures that the BoA may conclude are 'closely } \\
\text { related' could be helpful in achieving full compliance. More important, consolidation of } \\
\text { subsidiaries and affiliates' exposures should be provided for. Proposed amendments to } \\
\text { the BL, if implemented, should enable the BoA to meet this requirement. }\end{array}$ \\
\hline CP 10 & $\begin{array}{l}\text { It would be helpful if the BoA was also able to deem a relationship to be connected for } \\
\text { the purpose of the limits. It would also be consistent with recent corporate governance } \\
\text { developments in other major countries if exposures to connected parties were to be } \\
\text { disclosed in the bank's annual audited financial statements. }\end{array}$ \\
\hline CP 11 & $\begin{array}{l}\text { At present cross border risk is negligible but in due course the BoA should introduce } \\
\text { some more formal system of monitoring so that it can identify any such risks as and } \\
\text { when they arise. }\end{array}$ \\
\hline CP 15 & $\begin{array}{l}\text { The supervisory authority should have the authority to share information with foreign } \\
\text { financial sector supervisory authorities. } \\
\text { The supervisory authority should require banks to have a policy statement on ethics and } \\
\text { professional behavior and should require that banks communicate the policies clearly to } \\
\text { staff. }\end{array}$ \\
\hline CP 19 & $\begin{array}{l}\text { The draft new banking law contains a provision that enables the BoA to require that } \\
\text { boards of foreign banks meet at least twice a year in Albania and that at least one board } \\
\text { member be a resident of Albania during his tenure as a board member. This would } \\
\text { address the difficulty BoA now encounters in arranging for direct meetings with some } \\
\text { bank boards. } \\
\text { The BoA could also formalize its meetings with audit firms, e.g., by scheduling regular } \\
\text { post audit meetings. }\end{array}$ \\
\hline CP 20 & $\begin{array}{l}\text { The BL, supported by accompanying regulations, should allow supervisors to supervise } \\
\text { banking groups on a consolidated basis. } \\
\text { There should be formalized arrangements for information sharing among Albanian } \\
\text { supervisory authorities to minimize overlap in execution of responsibilities. }\end{array}$ \\
\hline CP 21 & $\begin{array}{l}\text { More specific guidance could be given to banks on the valuation of assets and collateral. } \\
\text { More regular meetings with external auditors coud help ensure that the BoA obtains full } \\
\text { value from the audit process. }\end{array}$ \\
\hline CP 24 & $\begin{array}{l}\text { BoA should continue its efforts to seek to formalize agreements with the supervisory } \\
\text { authorities who have not agreed to do so to date. } \\
\text { BoA needs to ensure that the draft banking law expands the authority of the BoA to } \\
\text { prohibit banks from establishing operations in countries with restrictions on information } \\
\text { flows. This is addressed in the new BL draft. }\end{array}$ \\
\hline CP 25 & $\begin{array}{l}\text { The BoA needs to assess whether home country supervisors practice consolidated } \\
\text { supervision, which would ensure that there is active home country supervision over } \\
\text { foreign banks' operations in Albania. }\end{array}$ \\
\hline
\end{tabular}




\section{Authorities' response to the assessment}

64. The Authorities thanked the FSAP team for the assessment and were in broad agreement with its findings, including that the supervisory framework could be enhanced in some areas. Most of these areas had also been identified in the self assessment which the BoA undertook in the lead-up to the FSAP update and several development projects are underway at the BoA targeted at addressing these.

\section{The CPSS CoRe PRINCIPLES}

\section{General}

65. This is a summary of the assessment of systemically important payment systems in Albania based on the Committee for Payment and Settlement Systems (CPSS) Core Principles (CPs) for Systemically Important Payment Systems (CPSIPS). The objective of the assessment is to identify potential vulnerabilities and inefficiencies in payment systems arrangements in Albania and provide some recommendations for their improvement. One system is assessed, the recently launched Real Time Gross settlement (RTGS) system, Albania Interbank Payment System (AIPS), that allows movements of funds among the accounts of financial institutions at the central bank. Securities settlement systems were not assessed because, although there is one stock exchange present in the country, securities markets are inactive. The main counterparty agency for the assessment has been the central bank (Bank of Albania, BoA).

66. Several documents were provided to the mission for the assessment, in particular an assessment of the AIPS performed in June 2004 by the Financial Services Volunteer Corps (FSVC). The mission met the Governor and Deputy Governor of the Central Bank, several departments of the BoA and commercial banks. The main tools used for the assessment have been the IMF-WB Guidance Note for Assessing Observance of Core Principles for Systemically Important Payment Systems and the CPSS Core Principles for Systemically Important Payments Systems.

\section{Institutional and market structure-Overview}

67. There are currently 17 commercial banks in Albania accounting for some 90 percent of all financial intermediary assets. All are majority owned by the private sector ( 2 Albanian and 15 foreign-owned). The financial sector also includes a small number of insurance companies, credit and savings institutions, and nonbank financial institutions.

68. The BoA is a legally independent entity, accountable to the Parliament, and has as its principal objective the maintenance of price stability. The BoA's primary monetary policy instruments are repo (and reverse repo) operations and outright transactions. To achieve its price stability goals, defined as inflation between 2-4 percent per annum, the BoA is expected to promote the liquidity, solvency and proper functioning of a stable, market-oriented 
banking system. Additionally, the BoA is responsible for the supervising banks, issuing domestic currency and promoting smooth payment system operation.

\section{Payment System Infrastructure-Overview}

69. Cash is the major means of making payments in Albania, although automated payment systems have been and are being developed. The BoA owns and operates a Real Time Gross Settlement (RTGS) system for inter-bank payments - the Albania Interbank Payment System (AIPS). The BoA is responsible for its regulation, design and administration. The AIPS was established to provide real time processing and settlement for high value payments in lek (above lek 1 million). These include payments in settlement of the netted outcome of the retail clearings, payments to and from the BoA in its role as banker for the government (including those to clear and settle primary market transactions in government securities), and interbank money market transactions. The AIPS system is located at the BoA and several departments share responsibility for its operation: the IT Department (technical operation); the Accounting and Payment Department (business operation); the Monetary Operations Department (intraday lending facility); the Internal Audit Department (governance and oversight); and the Supervision Department (enforcement vis-à-vis participants).

70. In addition to the AIPS, the BoA offers clearing services for retail paymentscurrently for payment orders and checks. It plans also to become the settlement agent for card payments. Retail payments are still relatively rudimentary with manual processes involving a on physical exchange of items during clearing sessions at the BoA. However, an automated clearing house $(\mathrm{ACH})$ has just been complete, with settlement amounts to be calculated on a multilateral net basis. Until recently, card payments had been insignificant, but the card infrastructure has begun to show rapid growth in 2004, mainly in Tirana. So far, card infrastructure is not designed to allow for full interoperability though some individual card facilities are linked to international systems. In addition, the Post Office provides services for low-value domestic payments and some money transfer operators (e.g., Western Union) specialize in cross-border services (particularly remittances). In an effort to increase the amount of cash entering the formal banking system, the government initiated, "Beyond Cash", a program led by the BoA to promote the use of bank accounts for payments purposes. Already government employees are paid by direct deposit into banking accounts. Also discussed is a mandatory shift of payments to and from government through banking channels by the end of 2005. A voluntary shift is so far ongoing. It is hoped that the transition to greater use of the formal system will be accompanied by improvements to infrastructure (for example a wider introduction of ATM and POS infrastructure) and changes to the business tax regime to encourage formal systems.

71. The securities market in Albania is at a very early stage of development and thus a well-functioning delivery-versus-payment system is not yet in place. At this point, there is a primary issuance market in government debt. Government securities are purchased predominantly by banks, but other institutions and individuals increasingly participate. Although banks undertake some retail transactions with their customers, they hold the 
majority of their purchases until maturity. A secondary market in government debt is virtually non-existent. There is no organized market in corporate securities and the over-thecounter market is nearly inexistent.

\section{Summary Assessment}

72. Currently, only one system is considered systemically important in Albania: the recently launched RTGS system, AIPS. In 2004, AIPS settled a total number of 25,881 payments, with an aggregate value of lek 1,971 billion. Daily average transactions amounted to about 120 for a value of around lek 6.0 billion. These amounts are far in excess of the other non-cash payment systems in Albania. Moreover, the netted result of Albanian retail payment systems (those based on payment orders, checks and prospectively VISA card payments) are settled through AIPS. The "Beyond Cash" initiative and the newly completed $\mathrm{ACH}$ project are expected to enlarge the role of AIPS. In the first place, interbank settlement deriving from payments processed in the ACH will take place through AIPS. Secondly, the "Beyond Cash" initiative is likely to bring about a substantial increase in the numbers and values of customer payments made through AIPS. The BoA will need to consider whether the ACH system should be considered a Systemically Important Payments System (SIPS) and, if not, whether it would nevertheless be desirable for it to comply with some or all of the CPSIPS.

73. In sum, the AIPS does not fully observe the CPSS CPSIPS, though most of the Principles are observed, at least in part. In particular, it fails to fully comply with Principle I (sound and legal framework), Principle III (managing financial risks), Principle VII (operational reliability and business continuity), Principle VIII (efficiency and practicality), and Principle X (governance). In order to observe all CPSIPS, some aspects of the system need to be considered and discussed more broadly with the financial community. These include an assessment of the legal risk, an extension of operating hours, an improvement of the overall efficiency of the system, an effective interconnection with other systems (e.g., the government securities settlement systems), routines for channeling government payments early in the operating day, and more effective governance arrangements. The overhaul of the system should therefore include, inter alia: (i) the implementation of a more robust and efficient communication network between the BoA and system participants (ii) the implementation and enforcement of strict security measures both for physical and electronic access to the system; (iii) the upgrade of contingency plans and disaster recovery mechanisms, including the current plans to place the secondary site outside the location of the primary site; and (iv) the implementation of very tight measures for business continuity and resilience. The redesign of the system should induce changes that could affect the efficiency and practicality of the system such as full integration of available systems, and reduction and eventually elimination of manual procedures and connection shortages. Governance aspects should be reconsidered both internally in the central bank, through a better definition of responsibilities among the different departments responsible for system operations, and with system participants, through the Participants Committee, established to address such issues. 
74. The BoA does not fully observe Responsibilities A, B, C, \& D of the CPSIPS and, therefore, needs to establish its oversight function over the payments system as a whole in the country. The BoA in exercising its oversight role should have the ability to carry out this function effectively. In order to enhance cooperation in the payments system, a formal cooperative body, led by the BoA, (National Payment System Council) has been recently created. Such a body will need to discuss issues of broad interest to its membership to permit action on a range of payment systems issues.

Table 5. Albania: Recommended Actions to Improve Observance of CPSS Core Principles and Central Bank Responsibilities in Applying the CPs

\begin{tabular}{|c|c|}
\hline Reference principle & Recommended action \\
\hline $\begin{array}{l}\text { Legal foundation } \\
\text { i.e., CP I } \\
\text { e.g., CP I-The system should } \\
\text { have a well-founded legal basis } \\
\text { under all relevant jurisdictions. }\end{array}$ & $\begin{array}{l}\text { During the short history of the AIPS system, there has been no relevant test in } \\
\text { court of any aspect of the system's legal foundation, but it is believed that there } \\
\text { is at least one significant flaw. This relates to the admissibility of electronic } \\
\text { records (including digital signature) as evidence. } \\
\text { The BoA offers an intraday liquidity facility (ILF) to AIPS participants, which } \\
\text { is intended to be secured by the participant's holdings of government debt } \\
\text { (Treasury bills) through repo arrangements. In practice, there seems to be some } \\
\text { doubt about the enforceability of the BoA's security interest in the event of the } \\
\text { participant's liquidation at a time when the loan is outstanding. It seems } \\
\text { possible that other classes of preferred creditor might rank before the BoA's } \\
\text { interest in the assets. } \\
\text { The BoA should address these issues as a matter of urgency. The BoA is } \\
\text { already working with the Ministry of Justice and the banks on relevant } \\
\text { improvements to the legal framework to support electronic means of payment. } \\
\text { It is very likely that external assistance from international experts will be } \\
\text { needed in this effort. Also, the authorities need to consider whether the number } \\
\text { and extent of legal changes will require an ad hoc payments system law or a } \\
\text { revision to the overarching law. }\end{array}$ \\
\hline $\begin{array}{c}\text { Understanding and } \\
\text { management of risks } \\
\text { i.e., CPS II-III } \\
\end{array}$ & \\
\hline $\begin{array}{l}\text { Settlement } \\
\quad \text { i.e., } C P S I V-V I\end{array}$ & $\begin{array}{l}\text { There is no evidence that liquidity in AIPS has presented any risks (other than } \\
\text { legal risks for the BoA) or major constraints to date or that throughput patterns } \\
\text { are unsatisfactory at current low levels of AIPS traffic. However, with regard to } \\
\text { liquidity risk, several factors should, however, be borne in mind for the future, } \\
\text { in view of the likely substantial increase in the number and value of payments } \\
\text { through AIPS in the medium term. In the first place, it should be noted that the } \\
\text { BoA is currently unable to administer the ILF in a flexible way, such that } \\
\text { liquidity is only made available to the extent necessary for payment throughput. } \\
\text { Secondly, the (helpful) early peak in activity seems to depend: (i) on a feature of } \\
\text { participant behavior that will not necessarily continue (namely the extent of } \\
\text { their input of payments for forward value-dates); and (ii) on early payments by } \\
\text { the BoA, which are presumably "lumpy" (for example the weekly maturities of }\end{array}$ \\
\hline
\end{tabular}




\begin{tabular}{|c|c|}
\hline Reference principle & Recommended action \\
\hline & $\begin{array}{l}\text { treasury bills), rather than a smooth daily feature. More sophisticated } \\
\text { management of liquidity issues may well become necessary in the future. } \\
\text { It is recommended that: } \\
\text { The BoA institute appropriate controls to remove the perceived } \\
\text { operational risk of a failure in the mechanism for blocking disposal of } \\
\text { treasury bills assigned to the BoA as security for ILF advances (and } \\
\text { other advances, if applicable). (This seems already to be in progress.) } \\
\text { Consideration be given to the desirability and practicality of alternative } \\
\text { approaches to intraday liquidity provision. For example: Is the current } \\
\text { 20 percent ceiling on deployment of required reserves lower than it } \\
\text { need be? Can a way be devised to overcome the technological and/or } \\
\text { procedural inhibitions that prevent the BoA from administering the ILF } \\
\text { in a more flexible way, in particular so as to avoid advancing excessive } \\
\text { amounts? } \\
\text { The BoA keep throughput behavior under review and periodically } \\
\text { reconsider the merits of throughput guidelines and/or price incentives } \\
\text { in the light of experience and changing circumstances. } \\
\text { - } \\
\text { In some circumstances, system's hours had to be extended to allow processing } \\
\text { of some payments. However, in all cases, the system was able to complete the } \\
\text { operating day successfully. } \\
\text { Appropriate controls should be put in place to ensure strict application of the } \\
\text { provisions on extensions to operating hours - in particular to ensure that internal } \\
\text { procedures in the BoA do not delay payments beyond normal operating hours } \\
\text { and }\end{array}$ \\
\hline $\begin{array}{l}\text { Security and operational } \\
\text { reliability, and contingency } \\
\text { arrangements } \\
\quad \text { i.e., } C P V I I\end{array}$ & $\begin{array}{l}\text { All pending issues should be addressed by the BoA as a matter of urgency. The } \\
\text { overhaul of the system should include, inter alia: (i) the implementation of a } \\
\text { more robust and efficient communication network between the bank and } \\
\text { system participants; (ii) the implementation and enforcement of strict security } \\
\text { measures both for physical and electronic access to the system; and (iii) the } \\
\text { upgrade of contingency plans and disaster recovery mechanisms, including the } \\
\text { current plans to place the secondary site outside the location of the primary site. } \\
\text { Implementation of very tight measures for business continuity and resilience is } \\
\text { also needed. }\end{array}$ \\
\hline $\begin{array}{l}\text { Efficiency and practicality of the } \\
\text { system } \\
\quad \text { i.e., } C P V I I I\end{array}$ & $\begin{array}{l}\text { The BoA will have to convene system participants to discuss any changes } \\
\text { required to further enhance the efficiency of the system. Required changes } \\
\text { include improvements to the connectivity, operating hours, and effective } \\
\text { interconnection with other systems (in particular with the government securities } \\
\text { settlement systems) and routines for channeling government payments early in } \\
\text { the operating day. } \\
\text { The current procedure used to obtain intra-day liquidity is not particularly } \\
\text { flexible, in that system participants have to post collateral in the Intraday } \\
\text { Liquidity Fund prior to the beginning of the operating day. The procedure has }\end{array}$ \\
\hline
\end{tabular}




\begin{tabular}{|c|c|}
\hline Reference principle & Recommended action \\
\hline & $\begin{array}{l}\text { two shortfalls: on one hand, banks will have the securities immobilized for the } \\
\text { entire day even if they will not use intra-day credit; on the other hand, banks } \\
\text { might not be able to access the facility for unexpected payments which exceed } \\
\text { the amount of securities posted in the morning. The BoA should constantly } \\
\text { monitor the extent to which this is creating an inefficiency in the system. } \\
\text { Pricing policies should be carefully formulated, discussed with system } \\
\text { participants and used to re-arrange payment transactions in a more efficient and } \\
\text { secure way among the available and future systems and instruments. }\end{array}$ \\
\hline $\begin{array}{l}\text { Criteria for participation } \\
\quad \text { i.e., } C P I X\end{array}$ & $\begin{array}{l}\text { The BoA could periodically reassess its policy regarding access and eventually } \\
\text { consider the inclusion of other institutions into the RTGS system, should the } \\
\text { need arise (e.g., securities operators should capital markets develop over time). }\end{array}$ \\
\hline $\begin{array}{l}\text { Governance of the payment } \\
\text { system } \\
\text { i.e., } C P X\end{array}$ & $\begin{array}{l}\text { Governance aspects should be reconsidered both internally in the central bank, } \\
\text { through a better definition of responsibilities among the different departments } \\
\text { responsible for system operations, and with system participants, through the } \\
\text { creation of formal user groups to be convened on a regular basis. } \\
\text { The system's internal governance arrangements might have to be streamlined } \\
\text { and clarified in order to make the management of the system more accountable } \\
\text { and transparent. The major responsibility should be assigned to a Payment } \\
\text { System Department able to consider all aspects related to the management of a } \\
\text { modern RTGS system with particular regard to business requirements and its } \\
\text { use for monetary policy operations. } \\
\text { Discussions about systems' design and improvement should occur under the } \\
\text { umbrella of a National Payment System Council. Such a body, under the } \\
\text { leadership of the BoA, has been recently set up to include representatives from } \\
\text { all major stakeholders with an interest in payments and securities clearance and } \\
\text { settlement systems improvements and will need to be used as the main tool also } \\
\text { to secure a constructive dialogue between regulators and market participants. } \\
\text { It is not clear how effective the Supervisory Council is in its ability to address } \\
\text { all issues related to the payments system that affect multiple departments. } \\
\text { The BoA should seek as a matter of urgency full observance of all CPSIPS. }\end{array}$ \\
\hline $\begin{array}{l}\text { Central Bank Responsibilities in } \\
\text { applying the CPs } \\
\text { i.e., Responsibilities } A-D\end{array}$ & $\begin{array}{l}\text { In the context of establishing the oversight function, appropriate secondary legislation } \\
\text { (bylaws, circulars, etc.) should be implemented as a matter of urgency to complete the } \\
\text { legal framework and ensure the secure foundation of payment mechanisms that } \\
\text { effectively contribute to the integrity, efficiency and safety of all financial markets and } \\
\text { the operation of monetary policy. } \\
\text { In the context of establishing the oversight function, the BoA should disclose publicly } \\
\text { its implementation strategies to achieve its objectives relating to all significant payment } \\
\text { system matters. With regard to policy objectives, consideration should be given to a } \\
\text { broadening of scope beyond the two traditional main objectives of efficiency and } \\
\text { reliability of payment systems to a wider set of issues including the promotion of } \\
\text { competition in the payment services market and the protection of consumer interests. } \\
\text { A policy statement, which includes the objectives, policy stance and instruments of the } \\
\text { oversight function should be prepared and discussed with all stakeholders in the } \\
\text { payments system. }\end{array}$ \\
\hline
\end{tabular}




\begin{tabular}{|c|c|}
\hline Reference principle & Recommended action \\
\hline & 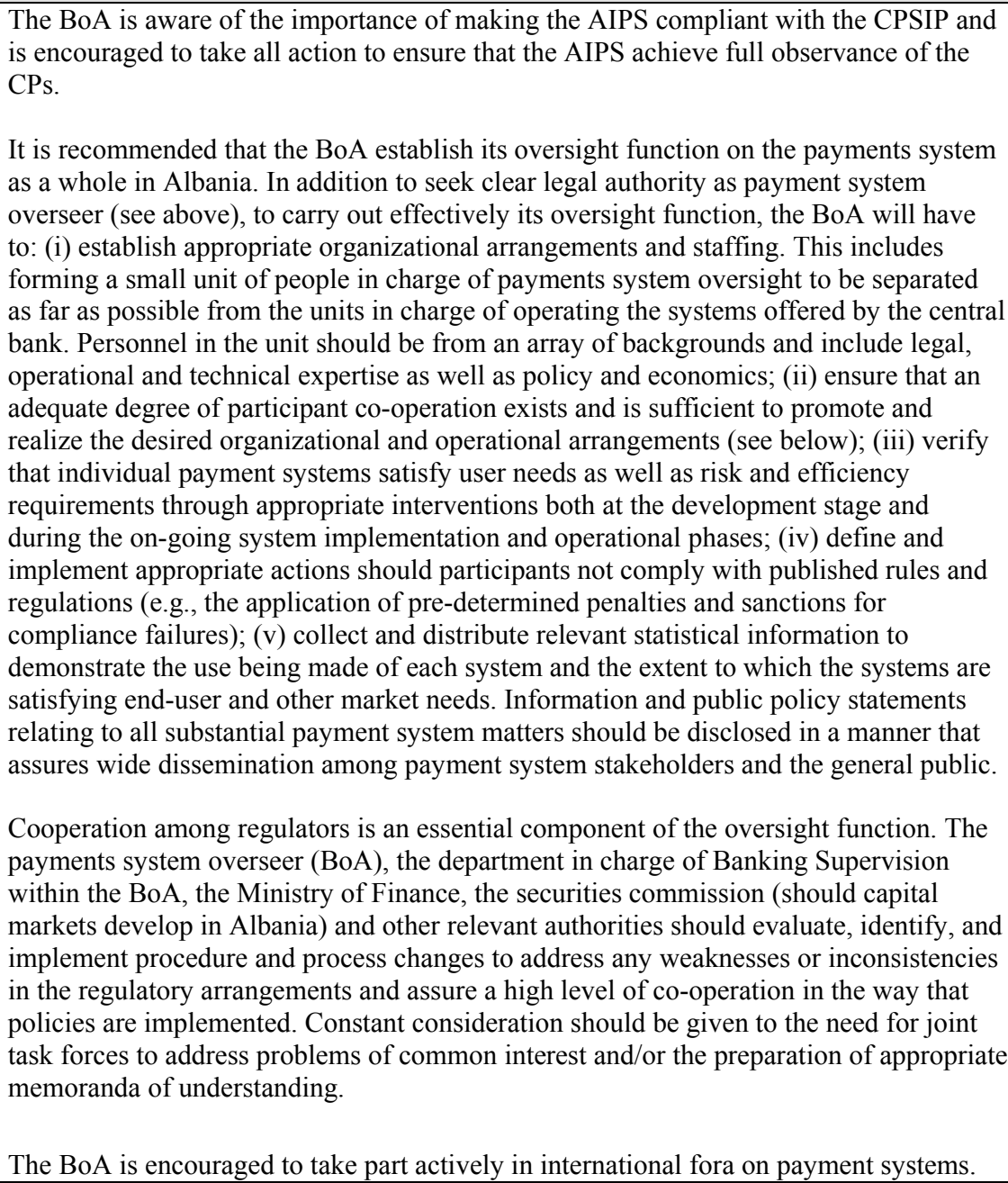 \\
\hline
\end{tabular}

\section{Authorities' response to the assessment}

\section{The authorities were in broad agreement with its findings, including that the payment} systems framework could be enhanced in some areas. 